\title{
Analisis Naratif Kebijakan: \\ Kebijakan Ganja Medis Di Indonesia
}

\section{OPEN ACCESS}

Citation: Asmoro, W., \& Lindiasari Samputra, P. (2021). ANALISIS NARATIF KEBIJAKAN: KEBIJAKAN GANJA MEDIS DI INDONESIA. Matra Pembaruan. 5(1), 13-24

Received: February 21, 2021

Accepted: May 7, 2021

Published: May 31, 2021

(c) The Author(s)

\section{cc) (i) (5) ()}

This work is licensed under a Creative Commons Attribution-NonCommercialShareAlike 4.0 International License.

Keywords: Medical Marijuana, Public Policy, Narrative Policy Analysis, Indonesian.
Kata Kunci: Ganja medis, Kebijakan Publik, Analisis Naratif Kebijakan, Indonesia.

\author{
Widi Asmoro ${ }^{\left(D_{1}\right.}$, Palupi Lindiasari Samputra ${ }^{\left(D_{2}\right.}$ \\ ${ }^{1,2}$ Program studi Ketahanan Nasional, Sekolah Kajian Stratejik Global (SKSG) Universitas Indonesia \\ Jl. Salemba Raya No.4 Jakarta 10430 \\ $\square$ palupi.ls@ui.ac.id
}

\begin{abstract}
Policy concern on medical marijuana utilization as diseases treatment or pain reliever still debated in many countries, also in Indonesia. This study aim to find government's narrative relate to medical marijuana policy in Indonesia, analyze the resistance of its implementation, and formulate alternative strategies. Narrative Policy Analysis (NPA) applied to analyze the narrative disparity on government's medical marijuana policies and to specify narrative form, as well as level of analysis, setting, character, plot, and moral of the policy narrative. Data gathered from trusted online documents such as public data, media coverage, or speech transcripts relevant to research issues from January 2019 to December 2020. Study find that 1) Government still forbid medical marijuana use in order to protect people from risk and unexpected problems; 2) Narrative policy develop by the government hampered by different belief system about marijuana and the lack of empirical study about medical marijuana in Indonesia; 3) Some of strategy recommendations to enhance government policy narrative related to medical marijuana were organize an open discussion with the contra community, conduct empirical study with academics to strengthen arguments and policy narrative, and socialize medical marijuana policy to various stakeholders.
\end{abstract}

Abstrak: Kebijakan terkait penggunaan ganja untuk pengobatan, meredakan, atau mengurangi gejala penyakit masih menjadi perdebatan di banyak negara, termasuk Indonesia. Artikel ini bertujuan untuk mengetahui narasi yang dibangun oleh pemerintah terkait dengan kebijakan ganja medis di Indonesia, menganalisis hambatan dari narasi kebijakan ganja medis, dan merumuskan alternatif strategi yang dapat dilakukan oleh pemerintah untuk menguatkan kebijakan ganja medis di Indonesia. Penelitian ini menggunakan Analisis Naratif Kebijakan (Narrative Policy Analysis / NPA) untuk menganalisis disparitas naratif dari kebijakan pemerintah tentang ganja medis dan menentukan bentuk naratifnya seperti tingkat analisis, setting, karakter, plot, dan moral dari narasi kebijakan. Data dikumpulkan dari dokumen online terpercaya seperti data publik, pemberitaan media, atau transkrip pidato yang relevan dengan masalah penelitian dari Januari 2019 s/d Desember 2020. Kesimpulan dari penelitian ini adalah 1) Pemerintah tetap melarang adanya pemanfaatan ganja untuk kepentingan medis dengan tujuan untuk melindungi seluruh masyarakat Indonesia dari masalah baru yang yang beresiko muncul; 2) Hambatan dari narasi kebijakan yang dibangun oleh pemerintah yaitu adanya perbedaan belief system terhadap tanaman ganja serta belum adanya kajian empiris tentang pemanfaatan ganja untuk kepentingan medis di Indonesia; 3) Rekomendasi strategi untuk memperkuat narasi kebijakan pemerintah terkait dengan pemanfaatan ganja medis diantaranya membuka ruang diskusi dengan kelompok masyarakat yang kontra narasi, melakukan uji empiris dengan melibatkan akademisi untuk memperkuat argumen dan narasi kebijakan pemerintah, serta mensosialisasikan kebijakan ganja medis ke berbagai stakeholder terkait. 


\section{Pendahuluan}

Ganja merupakan tanaman yang dianggap berbahaya oleh Undang-Undang Narkotika No. 35/2009 karena dapat menimbulkan efek halusinasi bagi pemakainya. Selain itu, tanaman ganja juga dapat menyebabkan ketergantungan/adiksi sehingga tanaman ini memang butuh pengawasan ketat mulai dari penanaman hingga pemanfaatannya. Diketahui bahwa ganja memiliki kandungan tiga senyawa utama yakni Cannabinol (CBN), cannabidiol (CBD) dan $\triangle 9$-Tetrahidrocanabinol (THC). THC sendiri merupakan senyawa pada ganja yang dapat mengakibatkan pemakainya mengalami euphoria dan halusinasi. Komposisi kandungan senyawa dalam ganja tersebut amat bergantung pada tempat tumbuhnya ganja. Sehingga setiap wilayah produksi ganja memiliki susunan senyawa tanaman ganja yang berbeda-beda (Pitri Susanti, 2012).

Berbeda dengan Undang-Undang Narkotika No.35/2009, tanaman ganja dalam Keputusan Menteri Pertanian (Kepmentan) No.104/2020 dikategorikan sebagai komoditas tanaman obat. Meskipun tidak berselang lama Kepmentan tersebut dicabut untuk sementara waktu, namun sebagian pihak yang mendukung legalisasi ganja medis menilai positif atas kebijakan Kementerian Pertanian tersebut.

Secara internasional, pemanfaatan ganja diatur dalam single Convention on Drugs 1961. Dalam Konvensi Tunggal Narkotika 1961 tersebut pemanfaatan ganja awalnya diatur dalam schedule I dan IV sebagai tanaman narkotika yang berbahaya dan butuh pengawasan ketat sehingga tidak dapat dikonsumsi sebagai obat. Namun atas rekomendasi dari Expert Committee on Drugs Dependence (ECDD) World Health Organization (WHO) di tahun 2019, kemudian pada sidang Commission on Narcotics Drugs (CND) di tahun 2020 diputuskan bahwa pengaturan pemanfaatan ganja dikeluarkan dari schedule IV Single Convention on Drugs 1961 sehingga dapat dimanfaatkan sebagai bahan pengobatan meskipun tetap berada dalam Schedule I yang artinya masih dalam pengawasan Internasional secara ketat (Humas BNN, 2020b).

Beberapa negara telah lebih dulu memanfaatkan ganja sebagai terapi medis. Seperti Jerman yang pada tahun 2017 resmi memperbolehkan warga negaranya untuk mengonsumsi ganja dengan syarat yaitu sedang sakit parah, telah berkonsultasi dengan dokter, dan tidak memiliki alternatif terapi medis lainnya (Berlinger, 2016). Kemudian di Kanada, ganja dapat digunakan untuk kepentingan medis dengan ketentuan telah terotorisasi dengan penyedia layanan kesehatan yang resmi dan terdaftar dengan perusahaan yang telah memiliki lisensi penjualan ganja dari pemerintah atau departemen kesehatan Kanada (Government of Canada, 2020).

Ganja atau cannabinoid yang digunakan sebagai terapi medis untuk mengobati atau meringankan penyakit atau gejala penyakit dipahami oleh Whiting et al. (2015) sebagai ganja medis. Ganja medis dapat dikonsumsi dengan cara dihisap, dihirup, dicampur dengan makanan, atau dibuat menjadi teh. Komite Pakar Ketergantungan Obat (ECDD) WHO menilai bahwa CBD yang terkandung dalam tanaman ganja mungkin memiliki manfaat terapi untuk sejumlah penyakit antara lain penyakit AlZheimer, penyakit Parkinson, depresi, kanker, diabetes, penyakit kardiovaskular, dan kecemasan (anxiety) (ECDD WHO, 2017).

Jika melihat dari sejarahnya, tanaman ganja memiliki sejarah panjang dengan peradaban manusia. Rekam jejak ganja yang dimanfaatkan sebagai pengobatan dapat ditemukan pada farmakope tertua di dunia yang bernama Pen-ts'ao ching. Farmakop tersebut diduga berasal dari jaman Kaisar Shen-nung yang berkuasa pada 2.700 SM. Selanjutnya penyebaran tanaman ganja meluas hingga mencapai India pada 1.000 SM. Di India ganja banyak digunakan untuk pengobatan/medis dan rekreasional. Sebagai bahan pengobatan ganja digunakan untuk mengobati penyakit epilepsi, rabies, gangguan kecemasan, rematik, dan beberapa penyakit gangguan pernafasan (Zuardi, 2005).

Selanjutnya seorang ahli pengobatan dari Persia yang bernama Ali al-Husain Ebn Abdullah Ebn Sina atau yang populer dikenal dengan Avicenna atau Ibnu Sina mencatat tentang efek ganda dari ganja. Menurutnya terdapat perbedaan efek yang didapat dari pemakaian ganja yakni efek euforia di awal pemakaian dan diikuti selanjutnya oleh efek disforik. Dalam catatannya tersebut, Avicenna menyebutkan bahwa ganja efektif 
mengobati asam urat, luka infeksi, edema, dan sakit kepala yang parah (Mahdizadeh, Ghadiri, \& Gorji, 2015).

Pemakaian ganja untuk pengobatan Barat pertama kali diperkenalkan oleh William O'Shaughnessy di tahun 1839. Shaughnessy yang merupakan seorang dokter asal Irlandia tertarik pada pengobatan menggunakan ganja pada saat dirinya bekerja di India. Ketertarikannya tersebut membawa dirinya melakukan berbagai penelitian untuk melakukan pengujian terhadap keamanan dan kemanjuran dari ganja. Hingga akhirnya Shaughnessy mendapatkan bahwa ekstrak ganja memiliki sifat analgesik dan dapat bertindak sebagai obat penenang. Shaughnessy menggunakan ekstrak ganja untuk menenangkan kejang otot pada pasiennya yang terkena tetanus dan rabies (Hand, Blake, Kerrigan, Samuel, \& Friedberg, 2017).

Di Indonesia, penelitian medis yang memanfaatkan ganja atau ekstrak ganja belum ada, namun penelitian sosial tentang pemanfaatan ganja sudah banyak dilakukan, diantaranya oleh Aldino (2018) yang meneliti persepsi mahasiswa Universitas Samudra (Unsam) terhadap legalisasi ganja di Indonesia. Hasil penelitiannya adalah mahasiswa Unsam memiliki persepsi yang netral terhadap gagasan legalisasi ganja serta cenderung setuju jika ganja dapat dimanfaatkan untuk kepentingan industri dan medis dan tidak setuju jika dimanfaatkan untuk rekreasional.

Adapula penelitian yang dilakukan oleh Lokollo et al. (2020) tentang kebijakan melegalkan penggunaan ganja sebagai bahan pengobatan. Dalam penelitiannya Lokollo menilai bahwa penggolongan ganja di Indonesia lebih baik diturunkan dari yang semula golongan I menjadi golongan II atau III agar dapat dimanfaatkan sebagai pengobatan penyakit atau gejala penyakit bukan digunakan secara bebas atau rekreasional. Penelitian lainnya yang dilakukan oleh Parama, Ranteallo, \& Kebayantini (2015) menyebutkan kelompok Lingkar Ganja Nusantara (LGN) berupaya untuk merekonstruksi ganja di masyarakat dengan cara memberikan informasi seputar manfaat ganja termasuk manfaatnya untuk pengobatan yang dapat diakses melalui internet.

Penelitian yang dilakukan oleh penulis memiliki perbedaan dengan penelitian terdahulu lainnya yaitu penulis mengkaji pemanfaatan ganja medis dalam ruang lingkup kebijakan publik. Meskipun terdapat penelitian terdahulu yang juga membahas kebijakan pemanfaatan ganja yang dilakukan oleh Putra (2014), yaitu Kebijakan Pendayagunaan Hemp (Ganja Industri) di Indonesia, namun yang menjadi berbeda adalah tujuan kebijakannya. Studi yang dilakukan oleh Putra berfokus pada pemanfaatan hemp (ganja industri) untuk kepentingan industri di Indonesia. Adapun hasil dari penelitiannya yaitu hemp dapat didayagunakan untuk meningkatkan kesejahteraan rakyat. Selain itu, beberapa kebijakan yang mendukung upaya pendayagunaan hemp adalah dengan membentuk badan pengawas hemp nasional, mengatur mekanisme pembudidayaan hemp oleh petani, serta mengatur mekanisme pemanfaatan hemp untuk kepentingan industri oleh instansi pemerintah.

Beberapa penelitian terdahulu tentang kebijakan tanaman obat, antara lain kebijakan publik tentang pengembangan tanaman obat di Indonesia oleh Siahaan \& Aryastami (2018) yang menyoroti masalah pengembangan tanaman obat di multi sektor antara lain: sektor kesehatan, pertanian, kehutanan, dan sektor informal. Hasil yang didapat dari penelitian tersebut adalah masih adanya gap antara kebijakan dengan pelaksaanaan pengembangan tanaman obat. Sehingga yang menjadi rekomendasi adalah perlunya kebijakan terobosan untuk meningkatkan pemanfaatan tanaman obat baik untuk kesehatan maupun ekonomi.

Studi lainnya tentang kebijakan publik tanaman obat dilakukan oleh Bahar (2016) yang membahas tentang pengembangan tanaman obat sebagai bentuk pemenuhan kebutuhan dan permintaan masyarakat dalam dan luar negeri. Hasil studi menunjukkan bahwa terdapat beberapa langkah strategis dalam pembinaan dan pengembangan tanaman obat, yaitu: 1) mengembangkan kawasan tanaman obat; 2) menerapkan budidaya tanaman obat yang baik; 3) mengembangkan desa organik berbasis tanaman obat; 4) menguatkan kelembagaan petani; 5) membentuk jaringan komunikasi dan informasi; 6) meningkatkan kapabilitas sumber daya manusia; dan 7) melakukan pendampingan terhadap petani/kelembagaan petani. 
Perbedaan penelitian ini dengan penelitian kebijakan publik terdahulu yang telah disebutkan di atas yakni terletak pada bidang kebijakannya. Penulis meneliti kebijakan pemerintah terkait pemanfaatan narkotika khususnya ganja di Indonesia sebagai bahan pengobatan atau terapi pengobatan bagi beberapa penyakit.

Meskipun dunia internasional telah memperbolehkan pemanfaatan ganja untuk memperbaiki kualitas kesehatan seseorang, namun CND memberikan otoritas kepada masing-masing negara termasuk Indonesia untuk mengatur pemanfataan ganja untuk kesehatan di negaranya. Atas dasar fakta-fakta tersebut, maka perlu dilakukan penelitian dengan pendekatan narasi untuk menganalisis bagaimana narasi kebijakan terkait ganja medis yang terjadi di Indonesia. Sehingga tujuan penelitian ini adalah 1) mengetahui narasi yang dibangun oleh pemerintah terkait dengan kebijakan ganja medis di Indonesia, 2) menganalisis hambatan dari narasi kebijakan ganja medis, dan 3) merumuskan rekomendasi strategi untuk menguatkan narasi pemerintah terkait dengan kebijakan ganja medis di Indonesia. Metode Narrative Policy Analysis (NPA) digunakan oleh penulis untuk menganalisis efektivitas narasi yang disampaikan oleh pemerintah atas kebijakan ganja medis di Indonesia.

Beberapa penelitian terdahulu yang juga menggunakan metode NPA sebagai metode analisis terhadap sejumlah kebijakan publik antara lain penelitian tentang kebijakan rokok elektronik di Kanada, Uni Eropa, Australia dan Amerika Serikat (O'Leary, Borland, Stockwell, \& MacDonald, 2017), kebijakan pendidikan di Amerika Serikat (Martinez, 2019), kebijakan ekonomi di Indonesia (Apriansyah, Purwadianto, \& Hanita, 2020), dan kebijakan ketahanan pangan di Indonesia (Dwiguna \& Munandar, 2020).

\section{Metode}

Penelitian ini menggunakan Narrative Policy Analysis (NPA) untuk menganalisa narasi kebijakan dari pemerintah. NPA adalah metodologi untuk memahami perdebatan akan suatu kebijakan yang kompleks dimana ada ketidakpastian, kerumitan, dan kebingungan yang meliputi isu kebijakan (The Open University, 2017).

NPA merupakan metode penelitian yang diciptakan pada masa postpositivis, dengan menganalisis cerita kebijakan yang dibuat dan disebarluaskan oleh para pelaku kebijakan dan masyarakat. Dalam kebijakan publik sebuah narasi mencerminkan pemahaman dari aktor-aktor kebijakan dan koalisinya tentang masalah serta solusi dari masalah tersebut melalui pengalaman dan posisi mereka dalam sistem dari kebijakan tersebut. Sehingga narasi kebijakan menjadi sumber pembuatan makna yang penting (Martinez, 2019).

Shanahan (2017) menekankan pentingnya bagi peneliti untuk menetapkan level analisis sebagai ruang lingkup penelitiannya. Level analisis tersebut terbagi menjadi 3 (tiga) yaitu level mikro, messo, dan makro. Level mikro artinya ruang lingkup penelitian terdapat pada individu yang membuat narasi dan pihak dibentuk oleh narasi. Level messo meneliti bagaimana peran aktor kebijakan seperti pemerintah dengan kelompok berkepentingan dalam proses kebijakan publik. Sedangkan level makro terkait dengan pengaruh ideologi, norma dan budaya terhadap proses narasi kebijakan.

Terdapat 2 (dua) hal penting yang dapat membantu peneliti untuk melakukan analisa terhadap sebuah narasi kebijakan, yakni elemen dan konten narasi kebijakan. Beberapa elemen narasi kebijakan yang terbentuk dan tersebar di masyarakat yakni (1) pengaturan (setting) yang terdiri dari ruang dan waktu; (2) karakter/aktor, yang terdiri dari protagonis, antagonis, dan korban; (3) pengorganisasian tindakan yang menghubungkan setiap karakter (plot); (4) pesan moral sebagai solusi kebijakan (moral of the story). Konten narasi kebijakan terdiri dari tata sistem nilai yang diyakini menjadi tujuannya (belief system), dan strategi (strategy) yang merupakan cara lain narator untuk memanipulasi atau mengendalikan proses kebijakan (Shanahan et al., 2017).

Level analisis dalam penelitian ini adalah level messo dengan menganalisis aktor kebijakan yaitu pemerintah dengan kelompok masyarakat yang resisten terhadap kebijakan tersebut. Data yang digunakan dalam penelitian ini adalah data sekunder 
yang bersumber dari dokumen online terpercaya seperti data publik, pemberitaan media, atau transkrip pidato yang relevan dengan masalah penelitian selama periode Januari 2019 s/d Desember 2020 serta beberapa dokumen penelitian terdahulu yang mendukung penulisan artikel.

\section{Hasil Dan Pembahasan}

III.a. Narrative Policy Analysis

Narasi kebijakan tentang ganja medis kembali muncul di tahun 2019, tepatnya setelah komite pakar untuk ketergantungan obat (ECDD) WHO mengusulkan ganja untuk diturunkan statusnya dari yang sebelumnya berada di schedule I dan IV menjadi hanya di schedule I. Adanya rekomendasi WHO ini didasarkan pada potensi manfaat yang dapat diperoleh dari ganja sebagai penunjang kesehatan. Kemudian untuk mensahkan rekomendasi tersebut oleh PBB selanjutnya akan dilakukan voting (Humas BNN, 2020b)

BNN menolak dengan tegas terhadap usulan dari ECDD WHO, karena menurut ahli farmasi BNN, mengonsumsi ganja dapat mengganggu kesehatan tubuh, efek ganja pada titik tertentu dapat menciptakan euphoria yang dapat mengakibatkan kecelakaan dan dampak buruk lainnya. Ganja adalah satu hal yang berbahaya, yang harus ada perlindungan maksimal untuk masyarakat dengan menggunakan sistem hukum negara (Humas BNN, 2020a).

Sejalan dengan kekhawatiran BNN, hasil penelitian dari Universitas San Fransisco, kebijakan melegalisasi ganja medis dapat secara tidak sengaja mempengaruhi penggunaan bersama rokok dengan ganja serta menciptakan tantangan baru yaitu menghentikan penggunaan tembakau di masyarakat (Wang, Ramo, Lisha, \& Cataldo, 2016), selain itu juga meningkatkan tingkat Cannabis Use Disorder (CUD) atau penyimpangan perilaku akibat penggunaan ganja (Yuan, Kanellopoulos, \& Kotbi, 2019).

Berdasarkan data yang dihimpun oleh Badan Narkotika Nasional di tahun 2019, ganja merupakan jenis narkotika yang paling banyak disalahgunakan di Indonesia sepanjang tahun 2018 dan mahasiswa menjadi kelompok yang paling banyak menyalahgunakannya (BNN, 2019). Kemudian hasil survey BNN di tahun 2020, yang dapat dilihat pada gambar 1 , menunjukkan bahwa ganja kembali menjadi jenis narkotika yang paling banyak disalahgunakan selama 1 tahun terakhir yakni 65,5\% dan penyalahguna terbanyak adalah masyarakat yang berusia produktif antara 3544 tahun (BNN, 2020). Dengan kata lain, ganja menjadi jenis narkotika yang paling banyak disalahgunakan di Indonesia setidaknya selama 2 tahun berturut-turut yakni tahun 2018 dan 2019.

Narasi penolakan dari pemerintah yang menjadi bentuk respon atas rekomendasi ECDD WHO tersebut menuai kritikan dari sejumlah kelompok masyarakat diantaranya adalah Rumah Cemara, LGN, IJRS, EJA, Yakeba, LBH Masyarakat, dan ICJR yang tergabung dalam Koalisi Masyarakat Sipil. Mereka menganggap penelitian-penelitian yang diklaim oleh pemerintah sebagai dasar pengambilan kebijakan tidak jelas dan cenderung mengada-ada (IJRS, 2020a). 
Gambar 1. Jenis Narkoba Paling Banyak Dikonsumsi Selama tahun 2019 (BNN, 2020)

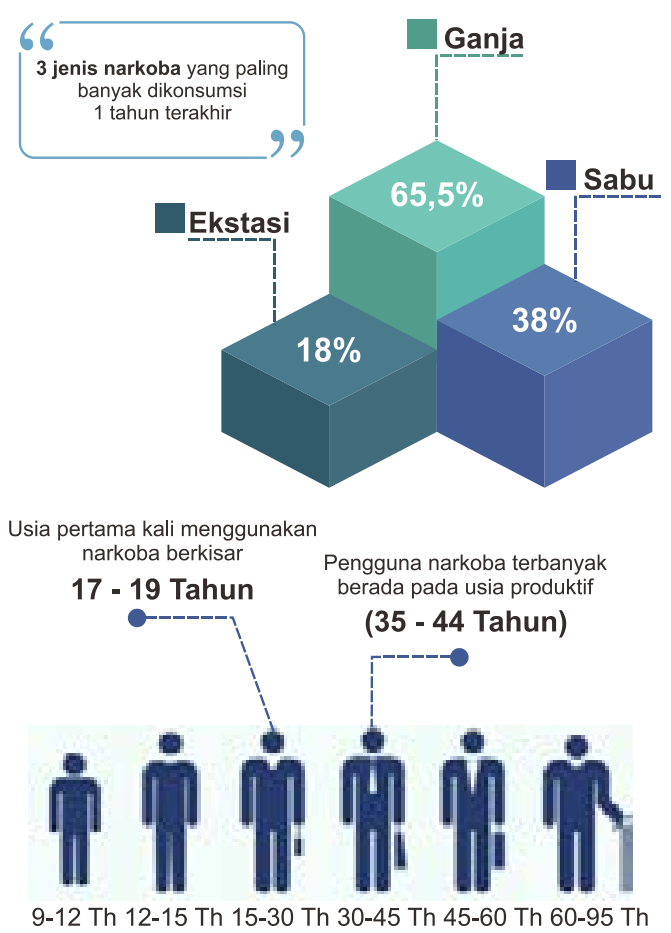

Sumber: Penelitian BNN dan Pusat Penelitian Masyarakat dan Budaya LIPI pada Populasi umum usia 15 64 tahun di 34 Provinsi.

Selanjutnya pada Desember 2020 rekomendasi tersebut disetujui dalam sidang Commission on Narcotics Drugs (CND). Hasil sidang tersebut memutuskan untuk mengeluarkan ganja dari schedule IV Single Convention on Narcotic Drugs 1961 agar dapat dimanfaatkan bagi kepentingan medis. Keputusan tersebut merupakan hasil voting yang diikuti oleh 53 negara. Meskipun ganja sudah keluar dari schedule IV atau daftar obat berbahaya, namun masih tetap terdaftar dalam schedule I atau daftar obat yang butuh kontrol internasional secara ketat (Humas BNN, 2020b).

Berbagai respon muncul dari dalam negeri menanggapi keputusan CND tersebut. Respon dukungan terhadap keputusan CND tersebut banyak dijumpai pada beberapa kelompok masyarakat yang menolak kebijakan pemerintah untuk melarang pemanfaatan ganja untuk kepentingan medis seperti LBH Masyarakat, IJRS, Yakeba, EJA, dan LGN. Mereka menjadikan momen perubahan kedudukan ganja dalam Single Convention On Narcotic Drugs 1961 dengan meminta pemerintah untuk dapat membuat kebijakan yang memperbolehkan ganja digunakan untuk kepentingan medis (IJRS, 2020b).

Beberapa pihak lainnya seperti aktivis ganja asal Aceh yang bernama M. Syariaf (Gil, 2020) dan tokoh politik dari Partai Keadilan Sejahtera, Rafli (Rosana, 2020) juga meminta pemerintah untuk melihat manfaat ganja untuk keperluan medis yang memiliki potensi keuntungan jika negara kita dapat mengekspor hasil tanaman ganja yang ada di Indonesia.

Namun, pemerintah memiliki respon yang berbeda atas keputusan sidang CND tersebut. Pemerintah melalui BNN dalam konferensi persnya menyampaikan bahwa negara Indonesia masih memiliki Undang-Undang Narkotika No. 35 Tahun 2009 yang mengatur pemanfaatan ganja dan turunannya. Selain itu hasil kajian yang dilakukan oleh sejumlah pakar kesehatan di Indonesia memperlihatkan hasil yang tidak sama dengan rekomendasi WHO-ECDD artinya perlu dilakukan kajian lebih mendalam mengenai karakter ganja. Dalam konferensi pers yang sama, pemerintah melalui BNN juga berharap kepada masyarakat Indonesia yang mengikuti proses pembahasan ini untuk dapat menyikapi persoalan ganja medis tersebut dengan bijaksana sebab Indonesia masih merupakan negara yang berdaulat yang memiliki peraturan perundang-undangannya sendiri untuk mengatur pemanfaatan ganja (Humas BNN, 2020b). 
Tabel 1. Komponen Narasi Kebijakan dalam Kebijakan Ganja Medis di Indonesia
Melalui narasi tersebut, BNN ingin menegaskan bahwa pemerintah tetap melarang penggunaan ganja yang sudah diatur dalam UU No. 35 Tahun 2009 tentang Narkotika. Dalam hal ini, ganja dikategorikan sebagai narkotika golongan I. Segala jenis narkotika yang masuk dalam golongan I adalah narkotika yang berpotensi tinggi membuat seseorang ketergantungan sehingga penggunaanya hanya dapat untuk pengembangan ilmu pengetahuan dan tidak dapat digunakan untuk kepentingan medis (Republik Indonesia, 2009).

Namun tidak semua aktor di luar pemerintah menentang kebijakan larangan penggunaan ganja medis, terdapat juga kelompok masyarakat seperti Granat yang mendukung kebijakan pemerintah tersebut. Menurutnya ganja dapat menghancurkan generasi muda (Koagouw, 2020)

Beberapa poin dalam narasi di atas telah menggambarkan bentuk naratif seperti level analisis, karakter serta setting yang digunakan dalam penelitian ini, dapat dilihat pada tabel 1. Untuk penggambaran plot yang menghubungkan setiap karakter dalam penelitian ini akan dibahas selanjutnya.

\begin{tabular}{|c|c|}
\hline \multicolumn{2}{|l|}{ Bentuk Naratif } \\
\hline Level analisis & $\begin{array}{l}\text { - Meso: Pemerintah Indonesia selaku } \\
\text { aktor pembuat kebijakan yang melarang } \\
\text { pemanfaatan ganja untuk kepentingan medis } \\
\text { yang berhadapan dengan sejumlah kelompok } \\
\text { masyarakat yang resisten terhadap kebijakan } \\
\text { tersebut. }\end{array}$ \\
\hline \multirow[t]{4}{*}{ Setting } & $\begin{array}{l}\text { - } \quad \text { Sidang CND telah menerima rekomendasi } \\
\text { dari ECDD WHO untuk mengeluarkan ganja } \\
\text { dari schedule IV sehingga status ganja } \\
\text { diperbolehkan untuk digunakan sebagai } \\
\text { pengobatan penyakit atau gejala penyakit } \\
\text { dengan pengawasan internasional yang ketat. }\end{array}$ \\
\hline & 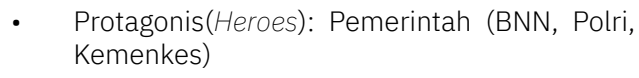 \\
\hline & $\begin{array}{l}\text { - } \text { Antagonis(Villain): Kelompok masyarakat } \\
\text { yang mendukung ganja medis dilegalkan (LBH } \\
\text { Masyarakat, ICJR, Rumah Cemara, LGN, IJRS, } \\
\text { EJA, dan Yakeba) }\end{array}$ \\
\hline & $\begin{array}{l}\text { - } \text { Korban(victim): masyarakat yang rentan } \\
\text { terpapar oleh dampak buruk ganja, khususnya } \\
\text { generasi muda. }\end{array}$ \\
\hline \multirow[t]{4}{*}{ Plot } & $\begin{array}{l}\text { - Komite Pakar untuk Ketergantungan Obat } \\
\text { WHO pada tahun } 2019 \text { merekomendasikan } \\
\text { untuk menghapus cannabis dan cannabis } \\
\text { resin dari schedule IV dan hanya ada di } \\
\text { schedule I Single Convention on Narcotic Drugs } \\
\text { 1961; }\end{array}$ \\
\hline & $\begin{array}{l}\text { - } \quad \text { Sidang Reconvened Sesi ke-63 CND yang } \\
\text { menerima rekomendasi ECDD WHO; }\end{array}$ \\
\hline & $\begin{array}{l}\text { - Pemerintah RI (Badan Narkotika Nasional) } \\
\text { masih mengatur penggunaan ganja dan } \\
\text { turunannya dalam golongan I UU No. } 35 \\
\text { Tahun } 2009 \text { tentang Narkotika; }\end{array}$ \\
\hline & $\begin{array}{l}\text { - Muncul resistensi dari berbagai kalangan } \\
\text { terkait sikap pemerintah tersebut. }\end{array}$ \\
\hline Pesan Moral & $\begin{array}{l}\text { - Pemerintah tetap melarang pemanfaatan } \\
\text { ganja untuk kepentingan medis dengan } \\
\text { tujuan untuk melindungi seluruh masyarakat } \\
\text { Indonesia dari masalah baru yang berisiko } \\
\text { muncul. }\end{array}$ \\
\hline
\end{tabular}




\begin{tabular}{l|l}
\hline Konten Narasi & $\begin{array}{l}\text { Ganja merupakan jenis narkotika berbahaya } \\
\text { yang memiliki efek halusinogen dan risiko } \\
\text { adiksi yang tinggi . }\end{array}$ \\
\hline Strategi & $\begin{array}{l}\text { Ganja merupakan jenis narkotika yang } \\
\text { memiliki manfaat untuk pengobatan penyakit } \\
\text { atau gejala penyakit. }\end{array}$ \\
\hline $\begin{array}{l}\text { Sosialisasi dampak buruk ganja terhadap } \\
\text { kesehatan melalui berbagai saluran media } \\
\text { sebagai bentuk upaya pemerintah dalam } \\
\text { menjaga kesehatan masyarakat; } \\
\text { Melakukan pengungkapan terhadap } \\
\text { peredaran gelap ganja sebagai bentuk } \\
\text { upaya menjaga ketertiban, keamanan, serta } \\
\text { kesehatan di masyarakat. }\end{array}$ \\
\hline
\end{tabular}

Sumber: Analisis Penulis

\section{III.b. Kontra Narasi Kebijakan Ganja Medis}

Bersumber dari Humas BNN, Kebijakan pemerintah yang menolak rekomendasi dari ECDD WHO tentang pemanfaatan ganja untuk kepentingan medis memiliki beberapa alasan yang mendasari, antara lain bahwa dari hasil penelitian kandungan ganja yang ada di Indonesia memiliki THC (kandungan dalam tanaman ganja yang sangat berbahaya karena bersifat psikoaktif) yang tinggi yakni 18\% dibanding dengan CBD yang hanya sebesar $1 \%$.

Alasan berikutnya adalah ganja yang dijadikan terapi pengobatan adalah ganja dari hasil budidaya rekayasa genetik yang dapat menghasilkan kandungan CBD tinggi dan kandungan THC rendah. Kemudian alasan terakhir yakni risiko penyalahgunaan ganja akan semakin besar jika ganja medis dilegalkan. Mereka yang ingin mengonsumsi ganja untuk rekreasi, bisa berdalih untuk terapi pengobatan.

Kebijakan dari pemerintah tersebut kemudian mendapat penolakan dari berbagai pihak seperti dari LSM, masyarakat pengguna manfaat medis dari ganja, dan beberapa akademisi. Penolakan tersebut merupakan bentuk resistensi terhadap narasi kebijakan yang dibangun oleh pemerintah. Berbagai permasalahan disampaikan melalui berbagai saluran media, diantaranya oleh Lembaga Bantuan Hukum Masyarakat (LBH Masyarakat) yang mewakili Koalisi Masyarakat Sipil yang menilai bahwa apa yang menjadi dasar penolakan dari pemerintah tersebut tidak memiliki data dukung secara ilmiah.

Menanggapi alasan perbedaan jumlah THC dan CBD pada tanaman ganja yang ada di Indonesia, seorang akademisi dari Universitas Syah Kuala berpendapat, dalam portal berita Tirto.id, bahwa kandungan dan dosis zat penyusun dalam ganja (THC dan CBD) dapat diatur jika memang ingin dimanfaatkan untuk keperluan medis.

Sementara itu beberapa peneliti telah mempublikasikan sejumlah manfaat dari ganja medis yakni dapat untuk mengobati mual dan muntah yang disebabkan oleh kemoterapi (Whitcomb et al., 2019), gangguan motorik kompleks pada anak (Blimkin et al., 2017), juga kejang epilepsi (Maa \& Figi, 2014). Dalam penelitian lainnya, pemakaian ganja medis dalam dosis rendah untuk pengobatan neuropatik terbukti aman tidak memiliki efek jangka pendek, meskipun masih perlu ada penelitian lanjutan untuk melihat efek jangka panjang dari pemakaian ganja medis tersebut (Lee, Grovey, Furnish, \& Wallace, 2018).

Pemerintah telah melakukan sejumlah upaya sebagai bentuk strateginya untuk mengendalikan jalannya proses kebijakan di masyarakat. Upaya tersebut antara lain dengan sosialisasi dampak buruk ganja bagi kesehatan yang ditujukan kepada seluruh masyarakat, khususnya mereka yang berisiko terdampak dengan adanya kontra narasi tersebut. Sosialisasi yang dilakukan melalui berbagai media komunikasi ini menjadi langkah yang diambil oleh pemerintah untuk mengendalikan narasi kebijakan yang terbentuk di masyarakat. 
Upaya lainnya adalah dengan mengungkap peredaran gelap ganja yang ada di masyarakat. Dengan banyaknya pengungkapan peredaran gelap narkotika jenis ganja dan disampaikan melalui berbagai media, ada pesan yang disampaikan oleh pemerintah yakni ganja merupakan ancaman tidak hanya bagi kesehatan masyarakat namun juga terhadap stabilitas keamanan di masyarakat. Upaya sosialisasi dan pengungkapan peredaran gelap ganja tersebut dilakukan oleh pemerintah sebagai bentuk upaya dalam menjaga keamanan, ketertiban, serta kesehatan di masyarakat. Filbey (2014) dalam penelitiannya mengungkapkan bahwa penggunaan ganja secara terus menerus dan berlangsung lama dapat mengakibatkan proses neuroadaptif dalam otak yang kompleks atau yang dikenal dengan istilah kecanduan/adiksi.

\section{III.c. Analisis Metanarasi}

Analisis metanarasi bertujuan untuk memetakan narasi utama yang dibangun oleh pemerintah terkait kebijakan ganja medis di Indonesia serta narasi kontra yang dibangun oleh kelompok masyarakat yang menghendaki dapat dimanfaatkannya ganja sebagai bagian dari pengobatan. Selain itu analisis metanarasi juga digunakan untuk mengetahui sebab perbedaan dari kedua narasi yang terbentuk di masyarakat. Metanarasi dalam tabel 2 digunakan sebagai alat menganalisa dua set narasi yang dibandingkan secara berhadapan untuk mempermudah dalam melakukan analisa. Hasil analisa metanarasi ini selanjutnya digunakan untuk mendapatkan solusi dari perbedaan narasi yang ada sehingga dapat diketahui apa yang menjadi hambatan dari keberhasilan narasi kebijakan pemerintah terkait pemanfaatan ganja untuk kepentingan medis. Solusi tersebut kemudian disusun menjadi langkah strategis sebagai rekomendasi yang dapat digunakan untuk mengendalikan proses kebijakan sehingga mencapai tujuan yang diharapkan oleh pemerintah.

Tabel 2. Perbandingan Antar Narasi

\begin{tabular}{|c|c|c|}
\hline Narasi Utama & Kontra Narasi & Sebab Perbedaan \\
\hline $\begin{array}{l}\text { Ganja sebagai obat hanya } \\
\text { bersifat simfomatik bukan } \\
\text { menyembuhkan }\end{array}$ & $\begin{array}{l}\text { Ganja dapat meredakan nyeri } \\
\text { neuropatik, menurunkan gejala } \\
\text { gangguan stress pasca trauma, } \\
\text { menurunkan gejala kejang pada } \\
\text { penderita epilepsi. }\end{array}$ & $\begin{array}{l}\text { Perbedaan belief system } \\
\text { yang berasal dari perbedaan } \\
\text { pandangan tentang tujuan dan } \\
\text { akibat dari pemanfaatan ganja } \\
\text { yang disampaikan oleh kedua } \\
\text { aktor. }\end{array}$ \\
\hline $\begin{array}{l}\text { Pengguna ganja medis lebih } \\
\text { untuk ingin menikmati efek } \\
\text { euphoria dan halusinasi yang } \\
\text { dapat mempengaruhi kejiwaan. }\end{array}$ & $\begin{array}{l}\text { Ganja yang dimanfaatkan untuk } \\
\text { kepentingan medis adalah yang } \\
\text { sudah berbentuk obat, bukan } \\
\text { yang masih berbentuk tanaman } \\
\text { dan juga tidak dikonsumsi } \\
\text { dengan cara dibakar dan dihisap. }\end{array}$ & \\
\hline $\begin{array}{l}\text { Ganja yang ada di Indonesia } \\
\text { tidak dapat digunakan sebagai } \\
\text { obat karena memiliki kandungan } \\
\text { THC yang lebih besar daripada } \\
\text { kandungan CBD }\end{array}$ & $\begin{array}{l}\text { Ganja dapat digunakan sebagai } \\
\text { pengobatan dengan cara } \\
\text { penyulingan untuk memisahkan } \\
\text { k o m o n e n-kom pon en } \\
\text { penyusunnya. }\end{array}$ & $\begin{array}{l}\text { Belum adanya kajian empiris } \\
\text { tentang pemanfaatan ganja } \\
\text { untuk kepentingan medis. }\end{array}$ \\
\hline $\begin{array}{l}\text { Ganja dapat mengakibatkan } \\
\text { adiksi yang tinggi. }\end{array}$ & $\begin{array}{l}\text { Belum ada penelitian } \\
\text { yang menyebutkan ganja } \\
\text { menyebabkan adiksi. }\end{array}$ & \\
\hline
\end{tabular}

Sumber: Analisis Penulis

Berdasarkan tabel 2 di atas terdapat gap narasi yang tercipta antara narasi utama dengan kontra narasi yang dibangun oleh kelompok-kelompok yang menghendaki ganja dapat digunakan untuk kepentingan medis. Dari tabel 2 tersebut terdapat 2 (dua) hal yang menjadi hambatan bagi narasi kebijakan yang dibangun oleh pemerintah yakni pertama, adanya perbedaan belief system terhadap tanaman ganja; kedua, belum adanya kajian empiris tentang pemanfaatan ganja untuk kepentingan medis. Pemerintah memandang ganja sebagai tanaman narkotika yang berbahaya sehingga tidak dapat dimanfaatkan untuk pengobatan. Sedangkan bagi sebagian kelompok 
masyarakat menganggap tanaman ganja meskipun berbahaya namun jika diolah sedemikian rupa akan memiliki manfaat sebagai pengobatan.

Metanarasi yang dihasilkan sebagai upaya pemerintah untuk melindungi seluruh masyarakat Indonesia dari masalah baru yang berisiko muncul dengan dilegalkannya ganja untuk kepentingan medis. Oleh karena itu dibutuhkan langkah-langkah strategis agar proses kebijakan yang ada dapat berjalan efektif dan tujuan bersama dapat tercapai.

Munculnya kontra narasi dalam kebijakan publik adalah hal biasa, sebagai respon atas kekhawatiran pihak-pihak terdampak atau mereka yang merasa tidak dilibatkan dalam proses kebijakan. Munculnya resistensi terhadap kebijakan publik, menunjukkan adanya perhatian dari kelompok masyarakat yang kritis terhadap kondisi ideal. Namun jika tidak diantisipasi, isu negatif yang muncul dapat terus berkembang dan rawan dimanfaatkan oleh pihak-pihak yang dengan sengaja bertujuan menyerang pemerintah.

\section{III.d. Rekomendasi Strategi Penguatan Narasi Kebijakan Ganja Medis}

Beberapa narasi kebijakan yang dibentuk oleh pemerintah adalah ganja hanya bersifat simfomatik bukan menyembuhkan suatu penyakit atau gejala penyakit; pengguna ganja medis hanya ingin menikmati efek euphoria dan halusinasinya; ganja dapat mengakibatkan adiksi yang berdampak pada meningkatnya biaya perawatan/ rehabilitasi; serta ganja yang ada di Indonesia memiliki kandungan THC yang lebih besar daripada kandungan CBD-nya sehingga dampak buruk yang dihasilkan lebih besar daripada manfaatnya.

Beberapa kelompok masyarakat tidak sepakat dengan narasi kebijakan dari pemerintah tersebut. Mereka mempercayai bahwa ganja memiliki manfaat sebagai tanaman obat sehingga diperbolehkan untuk dimanfaatkan sebagai bahan pengobatan atau bagian dari terapi pengobatan di Indonesia. Dalam kehidupan demokrasi, peran pemerintah adalah memfasilitasi proses pengambilan keputusan, bukan penentu utama dari suatu kebijakan. Oleh karena itu, beberapa langkah strategis sebagai bentuk rekomendasi untuk menguatkan narasi kebijakan pemerintah di masyarakat yaitu sebagai berikut:

1. Membuka ruang diskusi dengan kelompok-kelompok masyarakat yang menghendaki ganja diperbolehkan untuk kepentingan medis. Dalam diskusi tersebut pemerintah harus dapat menyajikan data-data dan informasi yang sahih dan lengkap mengenai aspek positif dan negatif dari penggunaan ganja, jumlah penyalah guna ganja di Indonesia serta dampak yang dapat terjadi jika ganja disalahgunakan.

2. Melakukan kajian empiris yang bertujuan untuk mengetahui potensi biaya yang akan dikeluarkan dan manfaat yang akan diperoleh jika ganja diperbolehkan untuk dimanfaatkan sebagai terapi medis. Kajian tersebut perlu melibatkan akademisi dan sebagian kelompok masyarakat untuk menciptakan kepercayaan dan demokrasi di masyarakat.

3. Hasil dari kajian tersebut kemudian dapat menjadi naskah akademik kebijakan ganja medis di Indonesia. Diharapkan penggunaan ganja medis dapat diatur sedemikian rupa sehingga orang-orang yang membutuhkan sebagai terapi medis dapat menggunakannya, sementara itu penyalahgunaannya dapat diatasi.

4. Hasil kebijakan pemerintah tersebut selanjutnya disosialisasikan ke berbagai kalangan seperti LSM, akademisi, media, dan stakeholder terkait lainnya sehingga diharapkan dapat menjaga dan meningkatkan ketahanan keamanan dan kesehatan masyarakat terhadap ancaman bahaya penyalahgunaan narkotika.

\section{Kesimpulan}

Berdasarkan hasil dan pembahasan terkait kebijakan ganja medis dengan pendekatan NPA, didapatkan beberapa kesimpulan, yaitu: pertama, narasi utama yang dibangun oleh pemerintah adalah tetap melarang pemanfaatan ganja untuk kepentingan medis dengan tujuan untuk melindungi seluruh masyarakat Indonesia dari masalah 
baru yang berisiko muncul, karena ganja merupakan jenis narkotika berbahaya yang memiliki efek halusinogen dan risiko adiksi yang tinggi. Kedua, hambatan dari narasi kebijakan yang dibangun oleh pemerintah adalah adanya perbedaan belief system terhadap tanaman ganja serta belum adanya kajian empiris tentang pemanfaatan ganja untuk kepentingan medis. Ketiga, rekomendasi strategi untuk memperkuat narasi pemerintah terkait kebijakan ganja medis di masyarakat diantaranya adalah membuka ruang diskusi dengan kelompok masyarakat yang kontra narasi; melakukan uji empiris dengan melibatkan akademisi untuk memperkuat argumen dan narasi kebijakan pemerintah; serta mensosialisasikan kebijakan ganja medis ke berbagai kalangan atau stakeholder terkait.

\section{Daftar Referensi}

Aldino, Hanri. (2018). Persepsi mahasiswa terhadap gagasan legalisasi ganja di indonesia. Jurnal Hukum Samudra Keadilan, 13(35), 234-249. https://doi.org/https://doi.org/10.33059/jhsk.v13i2.906

Apriansyah, Tofa, Purwadianto, Agus, \& Hanita, Margaretha. (2020). Narrative Policy Analysis : Trade-Off Pelayanan Dan Pengawasan Pasca Paket Kebijakan Ekonomi Xv. Jurnal Perspektif Bea Dan Cukai, 4(1), 1-19. http://jurnal.pknstan.ac.id/index.php/PBC/article/view/769

Bahar, Yul Harry. (2016). Kebijakan pengembangan tanaman obat. 33(66), 1-20. http://balittro.litbang. pertanian.go.id/wp-content/uploads/2016/12/Warta-33-No.-66-Desember_2016.pdf

Berlinger, Joshua. (2016). Germany to legalize medicinal marijuana by 2017. Retrieved March 25, 2021 , from CNN.com website: https://edition.cnn.com/2016/05/04/europe/germany-medicinal-marijuana/

Blimkin, L., Libzon, S., Bar-Lev Schleider, L., Saban, N., Levit, L., Zerem, A., Linder, I., Pelleg, K., \& LermanSagie, T. (2017). Medical cannabis in children with complex motor disorders. European Journal of Paediatric Neurology, 21, e219. https://doi.org/10.1016/j.ejpn.2017.04.1132

BNN. (2019). Indonesia drugs report 2019. Jakarta.

BNN. (2020). Indonesia Drug Report 2020.

Dwiguna, Adrianus R., \& Munandar, Adis I. (2020). ANALISIS NARATIF KEBIJAKAN PANGAN NASIONAL MELALUI PROGRAM FOOD ESTATE NARRATIVE ANALYSIS OF NATIONAL FOOD POLICY THROUGH THE FOOD ESTATE PROGRAM. Publica: Jurnal Administrasi Pembangunan Dan Kebijakan Publik, 11(2), 273-284. http://ojs.uho.ac.id/index.php/publika/article/view/15080

ECDD WHO. (2017). Cannabidiol (CBD). In ECDD Thirty-ninth Meeting. Retrieved from http://www.ncbi.nlm. nih.gov/pubmed/32310508

Filbey, Francesca M., Aslan, Sina, Calhoun, Vince D., Spence, Jeffrey S., Damaraju, Eswar, Caprihan, Arvind, \& Segall, Judith. (2014). Long-term effects of marijuana use on the brain. Proceedings of the National Academy of Sciences of the United States of America, 111(47), 16913-16918. https://doi.org/10.1073/ pnas.1415297111

Gil. (2020). Tarik Ulur Regulasi Ganja Medis di Indonesia. Retrieved December 24, 2020, from https:// wWw.cnnindonesia.com/nasional/20200831090732-20-540996/tarik-ulur-regulasi-ganja-medis-diindonesia

Government of Canada. (2020). What you need to know about cannabis - Canada.ca. Retrieved March 25, 2021, from Canada.ca website: https://www.canada.ca/en/services/health/campaigns/cannabis/ canadians.html\#a11

Hand, Andrew, Blake, Alexia, Kerrigan, Paul, Samuel, Phineas, \& Friedberg, Jeremy. (2017). History of medical cannabis. Cannabis: Medical Aspects, 9(4), 17-26. https://www.researchgate.net/ publication/316545890_History_of_medical_cannabis

Humas BNN. (2020a). BNN Tegas Menolak Legalisasi Ganja. Retrieved January 15, 2021, from https://bnn. go.id/bnn-tegas-menolak-legalisasi-ganja/

Humas BNN. (2020b). Hasil Voting Pada Reconvened 63rd Session Commision On Narcotics Drugs Terkait Cannabis dan Cannabis Resin. Retrieved January 5, 2021, from https://bnn.go.id/hasil-voting-padareconvened-63rd-session-commision/

IJRS. (2020a). [Rilis Pers] Koalisi Masyarakat Sipil Meminta Dasar Pemerintah Menolak Rekomendasi WHO terkait Ganja Medis untuk Dibuka ke Publik. Retrieved January 15, 2021, from http://ijrs.or.id/rilispers-koalisi-masyarakat-sipil-meminta-dasar-pemerintah-menolak-rekomendasi-who-terkait-ganjamedis-untuk-dibuka-ke-publik/

IJRS. (2020b). PBB Ubah Sistem Penggolongan Narkotika yang Memperkuat Posisi Ganja Medis. Retrieved January 5, 2021, from http://ijrs.or.id/pbb-ubah-sistem-penggolongan-narkotika-yang-memperkuatposisi-ganja-medis/

Koagouw, Miechell Octovy. (2020). Semua yang Usul Legalisasi Ganja Patut Dicurigai - Peristiwa |. Retrieved December 9, 2020, from rri.co.id website: https://rri.co.id/nasional/peristiwa/890900/semua-yangusul-legalisasi-ganja-patut-dicurigai

Lee, Gemayel, Grovey, Brittany, Furnish, Tim, \& Wallace, Mark. (2018). Medical Cannabis for Neuropathic Pain. Current Pain and Headache Reports, 22(1). Retrieved from http://www.embase.com/search/ results? subaction=viewrecord\&from=export\&id=L620498523\%0Ahttp://dx.doi.org/10.1007/s11916018-0658-8

Lokollo, Leonie, Salamor, Yonna Beatrix, \& Ubwarin, Erwin. (2020). Kebijakan Formulasi Undang-undang Narkotika Dalam Legalisasi Penggunaan Ganja Sebagai Bahan Pengobatan di Indonesia. Jurnal Belo, 5(2), 1-20. https://doi.org/10.30598/belovol5issue2page1-20 
Maa, Edward, \& Figi, Paige. (2014). The case for medical marijuana in epilepsy. Epilepsia, 55(6), 783-786. https://doi.org/10.1111/epi.12610

Mahdizadeh, Shahla, Ghadiri, Maryam Khaleghi, \& Gorji, Ali. (2015). Avicenna's Canon of Medicine: a review of analgesics and anti-inflammatory substances. AJP, 5(3), 182-202. https://www. researchgate. net/publication/275339325_Avicenna's_Canon_of_Medicine_A_review_of_analgesics_and_antiinflammatory_substances

Martinez, Magdalena. (2019). An Examination of Higher Education Policy Problems Using Narrative Policy Analysis. American Behavioral Scientist, 63(3), 369-386. https://doi.org/10.1177/0002764218820569

O'Leary, Renée, Borland, Ron, Stockwell, Tim, \& MacDonald, Marjorie. (2017). Claims in vapour device (e-cigarette) regulation: A Narrative Policy Framework analysis. International Journal of Drug Policy, 44, 31-40. https://doi.org/10.1016/j.drugpo.2017.03.004

Parama, I. Dewa Made Satya, Ranteallo, Ikma Citra, \& Kebayantini, Ni Luh Nyoman. (2015). Peran lingkar ganja nusantara dalam legalisasi ganja. Jurnal Sosial, 2, 1-12. https://ojs.unud.ac.id/index.php/sorot/ article/view/12725

Pitri Susanti, Ni. (2012). Identifikasi Kandungan Cannabinoid Dalam Ekstrak Batang Ganja Dengan Metode Al-Tlc Dan Hptlc Spectrophotodensitometry. Indonesian Journal of Legal and Forensic Sciences, 2(1), 282193. Retrieved from https://ojs.unud.ac.id/index.php/ijlfs/article/view/3249

Putra, M. Taufan Perdana. (2014). KEBIJAKAN PENDAYAGUNAAN HEMP (Ganja Industri) UNTUK KEPENTINGAN INDUSTRI DI INDONESIA. Jurnal Hukum, 8. https://media.neliti.com/media/ publications/34922-ID-kebijakan-pendayagunaan-hemp-ganja-industri-untuk-kepentingan-industridi-indone.pdf

Republik Indonesia. (2009). Undang-Undang No. 35 Tahun 2009 tentang Narkotika. http://luk.staff.ugm. ac.id/atur/UU35-2009Narkotika. pdf

Rosana, Fransiscus Christy. (2020). Politikus PKS Jelaskan Rencana Legalisasi hingga Ekspor Ganja - Bisnis Tempo.co. Retrieved December 24, 2020, from https://bisnis.tempo.co/read/1302001/politikus-pksjelaskan-rencana-legalisasi-hingga-ekspor-ganja/full\&view=ok

Shanahan, Elizabeth A., Jones, Michael D., \& McBeth, Mark K. (2017). How to conduct a Narrative Policy Frameworkstudy. Social Science Journal, 55(3), 332-345. https://doi.org/10.1016/j.soscij.2017.12.002

Siahaan, Selma, \& Aryastami, Ketut. (2018). Studi Kebijakan Pengembangan Tanaman Obat di Indonesia. 157-166. http://ejournal2.litbang.kemkes.go.id/index.php/mpk/article/download/119/426

The Open University. (2017). Research methods: Narrative policy analysis. Retrieved December 9, 2020, from https://www.open.edu/openlearncreate/mod/oucontent/view. php?id=13636\&section=5.1

Wang, Julie B., Ramo, Danielle E., Lisha, Nadra E., \& Cataldo, Janine K. (2016). Medical marijuana legalization and cigarette and marijuana co-use in adolescents and adults. Drug and Alcohol Dependence, 166, 32-38. https://doi.org/10.1016/j.drugalcdep.2016.06.016

Whitcomb, B., Lutman, C., Pearl, M., Medlin, E., Prendergast, E., Robison, K., \& Burke, W. (2019). Use of cannabinoids in cancer patients: A Society of Gynecologic Oncology (SGO) clinical practice statement. Gynecologic Oncology, 157(2), 307-311. https://doi.org/10.1016/j.ygyno.2019.12.013

Whiting, Penny F., Wolff, Robert F., Deshpande, Sohan, Di Nisio, Marcello, Duffy, Steven, Hernandez, Adrian V., Keurentjes, J. Christiaan, Lang, Shona, Misso, Kate, Ryder, Steve, Schmidlkofer, Simone, Westwood, Marie, \& Kleijnen, Jos. (2015). Cannabinoids for medical use: A systematic review and meta-analysis. JAMA - Journal of the American Medical Association, 313(24), 2456-2473. https://doi.org/10.1001/ jama.2015.6358

Yuan, Melissa, Kanellopoulos, Theodora, \& Kotbi, Nabil. (2019). Cannabis use and psychiatric illness in the context of medical marijuana legalization: A clinical perspective. General Hospital Psychiatry, 61(July), 82-83. https://doi.org/10.1016/j.genhosppsych.2019.08.003

Zuardi, Antonio Waldo. (2005). History of cannabis as a medicine: a review. Brazilian Journal of Psychiatry. https://doi.org/10.1590/s1516-44462006000200015 